\title{
Sediment waves: geohazard or geofeature?
}

Victoria PUTANS, Russia

P.P.Shirshov Institute of Oceanology, RAS

Topic H: geophysics of the marine environment

\section{INTRODUCTION}

The term "sediment waves" fully established in Special issue of Marine Geology [192, 2002] presents large-scale depositional bedforms in various parts of World Ocean. These undulating objects usually have is tens of meters to a few kilometers in wavelength and are several meters high and were generated beneath a near-bottom current or turbidite or both. The main question about the sedimentary wavy features was, and is, to distinguish them from soft sediment deformations. The criteria for such distinguishing is a) accurate processing of seismic sections to reveal whether the faults are real, b) top-wings granulometric distribution, c) regular morphology with obvious distribution law, d) form of crests in plan view. However, "current vs creep" argument is still common even for some well-known "wave fields" [e.g. Berndt et al., 2006].

Worldwide investigations of last decade revealed these controversial geomorphologic features in different geological and paleogeological environments, including ones connected with oil, gas, and gas hydrates fields [Riedel et al., 2010; Heinio \&Davies, 2009; Holbrook et al., 2002]. The revealed facts that sediment waves a) can be not only confused with but be complicated by creep processes [Mitchell\&Huthnance, 2007], b) are evidence for present or past active environment, e.g. turbid flows, trigging, gas eruption [Putans et al., 2010], c) due to lithologically sorted material can be small-scale reservoirs both for free gas and fluids [Wynn et al., 2007, Booth et al., 2003], lead to assumption that presence of these geofeatures may be direct indicator of "geological state that represents or has the potential to develop further into a situation leading to damage or uncontrolled risk" e.g. geohazard. However, the same facts could reveal sediment waves themselves as treacherous features.

Due to recently increased awareness of ecological consequences of offshore exploration, geohazard estimation has become the first thing to do especially in marine environment. Since any sea is very sensitive to any external impact, any information on risk criteria could be vital. Processing of seismoacoustic data and analysis of acoustic field anomalies are primary methods of geophysical survey. Re-interpretation and comparative analysis could be of much help in estimation of potential hazards and especially in distinguishing perilous setting and safe geofeatures. The paper represents such analysis made by P.P.Shirshov Institute of Oceanology RAS on examples from Caspian Sea.

\section{GEOLOGICAL SETTING}

Caspian Sea is a huge $(1200 \mathrm{~km} \times 300 \mathrm{~km})$ in-land depression, isolated from World Ocean. Morphologically Caspiy can be divided into three regions: Northern (vast shelf plains), Central (depression, average depth $300 \mathrm{~m}$, maximum depth $-700 \mathrm{~m}$ ) and South (depression, average depth $500 \mathrm{~m}$, maximum $>1000 \mathrm{~m}$ ). Natural borders of these regions are Mangyshlak Threshold (sediment bow-shaped body) between North and Central parts and Apsheron Threshold (linear tectonic elevation) between Central and South parts (Figure 1). Significat regional processes are neotechtonic movements and great amount of deep-focus earthquakes (up to hundred each year). This trigging initiates mud vocano activity and mass movements on slopes of both deep basins. On the other hand, sedimentation processes in Caspian are controlled by bottom topography and sources of sedimentary material (rivers runoff first of all). The most famous Caspian pequliarity is its ever-lasting unpredictable level-change which is impossibble to correlate definitely neither with World Ocean nor with glaciation history. 

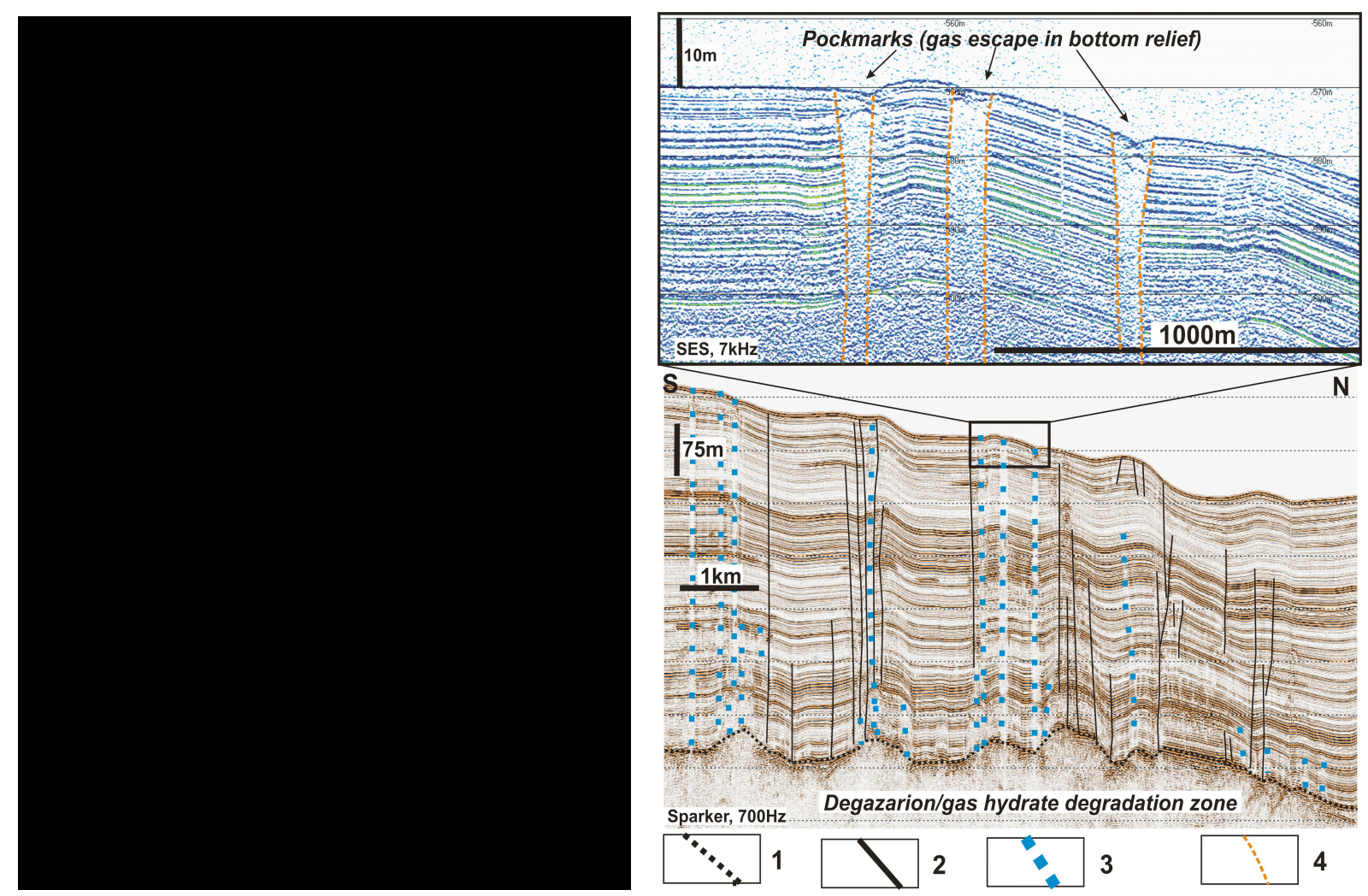

Figure 1 (left): Geomorphiligy scheme combined with scheme of heat flow from [Glumov, 2004]. Heat flow: A - most active, B - active, C - high; D - location of profiles on figures 2 and 3.

Figure 2 (right): Vertical degazation zones and pockmarks in bottom relief. 1 - top of gas hydrate degradation layer; 2 - falures; 3 - gas pipes; 4 - pokmarks. 1

Major hydrocarbon fields are situated on the Northern shelf and in deep Southern basin, and several prospective sructures occur in Central basin. There is a general distribution rule: main oil fiels are situated nothward from Apsheron threshold and main gas fields southward. Such situation is due to sedimetation history and heat flow which is especially great near Apsheron threshold. Nevertheless, gas-saturated sediments in different forms occur nearly everythere in Caspian. Most usual acoustic anomaly for such sediments is "bright spot", but spectatular gas pipes exists as well (Fig.2).

Beside oil and gas fields, Caspian sea seems to have several fields of gas hydrates with different gas types. During intensive expropation in South Caspian gas hydrates were discovered offshore Azerbaijan both on the top of mud volcanoes [Ginsburg \& Soloviev, 1994] and in fairly undisturbed sedimentary section by clear seismic BSR [Diaconescu et al., 2001]. Zones A on heat flow map adopted from Glumov [2004] on Figure 1 correlate with "allowed existence" areas caluculated from parameters in Diaconesu [2001].

\section{STUDY METHODS}

During recent investigations of P.P.Shirshov Institute of Oceanology seismoacoustic data was aquired by several hardware sets (Table 1). A global positioning system (DGPS) provided vessel position with an accuracy $0.5-5.0 \mathrm{~m}$. Polygons consist of orthogonally or obliquely crossing survey lines. The deposits have been sampled with gravity cores $15 \mathrm{~cm}$ in diameter and up to $4 \mathrm{~m}$ deep. Grain size analyses were made in MSU laboratories with standard methods. Volume density of unstrained and wet sediment was calculated by cutting ring method. Seismoacoucstics data was processed in 
RadExPro seismic processing program with standard algorithm (muting, filtration, sometimes deconvolution). Plastic models, based on density and geometry, were calculated in FLAC ${ }^{3 \mathrm{D}}$.

Table 1: Hardware parameters

\begin{tabular}{|c|c|c|c|c|}
\hline Type & Function & $\begin{array}{l}\text { Frequency } \\
\text { range }(\mathrm{kHz})\end{array}$ & $\begin{array}{l}\text { Penetration } \\
\text { (depend on sediments) }\end{array}$ & $\begin{array}{l}\text { Vertical } \\
\text { resolution }\end{array}$ \\
\hline Sparker & Seismoacoustic & $0.2-0.7$ & $50 m-300 m$ & $2-3 m$ \\
\hline $\begin{array}{l}\text { SES - } 2000 \\
\text { standart }\end{array}$ & $\begin{array}{l}\text { Echo-sounder }+ \\
\text { seismoacoustical } \\
\text { profiler (tone signal) }\end{array}$ & $\begin{array}{l}100 \mathrm{kHz} \\
4-12 \mathrm{kHz}\end{array}$ & $10 m-50 m$ & $0.05-0.15 \mathrm{~m}$ \\
\hline CHIRP-II & $\begin{array}{l}\text { Seismoacoustic profiler } \\
\text { with swip signal }\end{array}$ & $2-7 \mathrm{kHz}$ & $2 m-50 m$ & $0.2-0.5 \mathrm{~m}$ \\
\hline
\end{tabular}

RESULTS

Seismoacoustic data of high resolution shows distinct zonality of geomorphology and acoustic anomalies: bright spots and numerous filled paleovalleys in Northern Caspian; fans and paleodeltas on Mangyshlak theshold with creep zone and channel system down to Cenral basin; gas chimnes and unexpected mud volcano in basin itself; series of modern faults on Apsheron threshold; several fans and gas escaping zones in Southern Caspian.

The most significant event of recent years was discovery of several types of sediment waves on slopes of Central basin. The most vast $(\sim 150 \mathrm{~km} \times 50 \mathrm{~km})$ field is situated on western slope of the Central Basin (Fig. 3). Previously, these forms were interpreted as creep, but reinterpretation of old and obtaining new data showed all distinctions of mixed sediment waves (see Introduction). There are several generations of waves, interbedded with conform parallel deposits. Geological samples show numerous sand/clay thin layers. The whole sequence age is $700 \mathrm{kyr}$ and it has form of a wedge between the shelf break and the steep step down to abyssal.

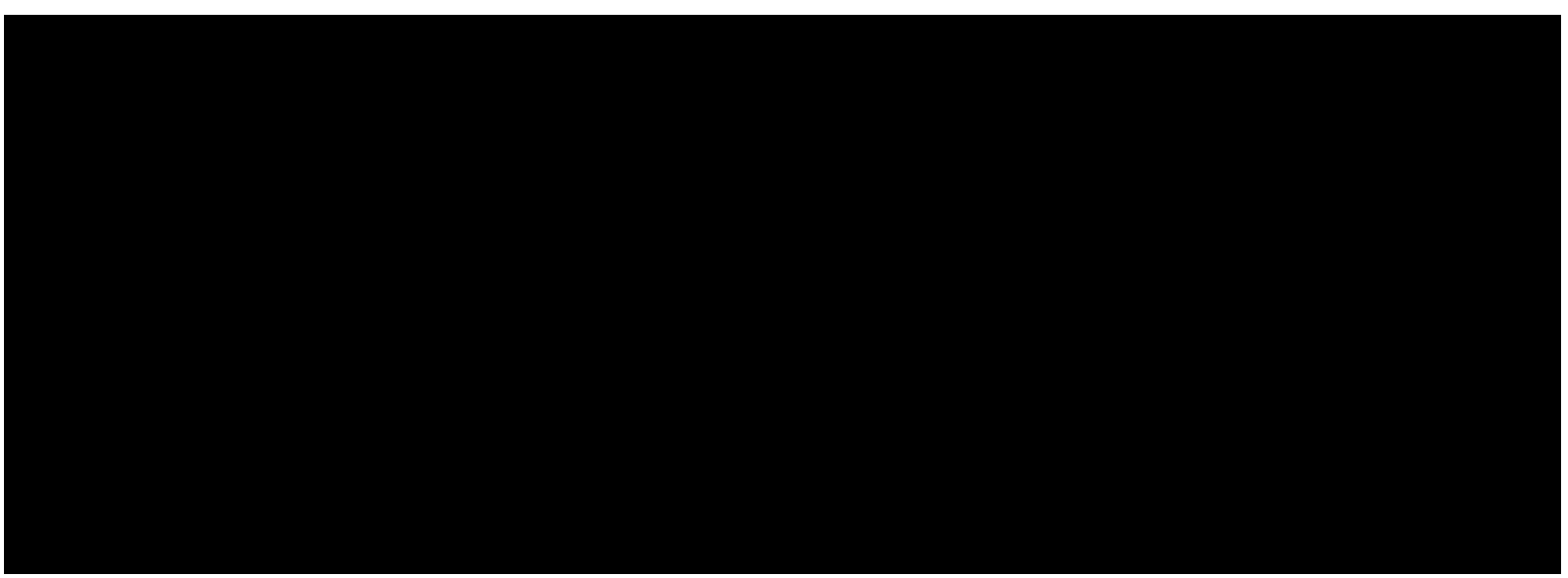

Figure 3: Sediment was on Derbent slope (Central Caspian). None zones of acouatic shadows on Sparker profile and reflections in water on SES data.

The second area of sediment waves is on levees of channels/canyons on Mangyshlak Thresold. Compund fan of paleo Volga, paleo Terek and paleo Ural represents a highly complicated system with inflows and meanders, both recent and old (up to $600 \mathrm{kyr}$ ). Sediment waves on levees show different morphology, probably because of not precisely normal transsections. Samples show thin material (clay). The very recent studies (2012) reveal the third sediment waves field on northern slope of Apsheron threshold. However it is a matter of future research. 
In close neighboughood with levee exists creep area. Folds have "classical" creep shape: flat tops, narrow valleys, irregular morphology and geometry. As well as on other "wavy" fields, there are several "generations" of creep folds, each slightly differs from others. Geological cores show watersaturated plastic clay.

Due to tectonic activity of the region, there are a lot of faults and failure of different scale. These features are inevitably connected to vertical zones without correlation (pipes and chimneys). Most of these zones ends with pockmarks in bottom relif (Fig.2). The other end connects with vast zone of chaotic reflections, both in Central ans South Caspian. However, northward from Asheron Threshold there are three such zones on different levels and none of them comes up to bottom surface, whlie sothward the zone occure just below holocene sediments.

\section{DISCUSSION}

Due to recently increased interest to gas hydrates and awareness of ecological consequences of hydrocarbon exploration, author put special attention on correlation between sediment waves, gas escaping structures and gas hydrates with their principle evidence bottom-simulating reflectors (BSR). Indeed, all these features seem to show up together on perspective hydrocarbon fields. The most obvious explanation to this correlation could be unstable environment which works both ways: endogenous processes form rough relief, cause trigging, sedimentation results in wavy forms, which could a) be unstable or b) accumulate escaping gas due to well sorted material. The most noticeable is escaping of free gas below BSR or from dissociated gas hydrates layers. Such correlation is not absolute and requires further investigations. However, it is possible to classify two types of "gassediment waves" relation: a) direct escaping of gas through wavy features; b) geological association "sediment waves - BSR" on seismoacoustic transects.

Interpretation of high resolution profiles on Caspian Sea, taken in framework of this conception, provides good evidence for such distribution. For example, on Derbent slope there are several "bright spots" and escaping chimneys. Modeling of plastic deformation shows that wedge of sediment waves on Derbent slope is stable, while creep on the northern slope is in continuous flowing. Between them sets channel system which indicates active hydrodynamics in recent past or present. Several levels of this system also have "bright spot" anomalies and series of possible gas-escape unconformities. Thus it is possible to declare that in Central Caspian sediment waves are evidenses of geohazards [Putans et al., 2010]. But the flow and fluxes are not the only geohazard sediment waves could be conected with.

Just nearby last levee starts acoustic anomaly of great disturbance. This anomaly is connected to gas pipes and is believed to be weak layer of dissociated gas hydrates. Presence of free gas could be dangerous for drilling on nearby structures, and further southward. Data from Apsheron Threshold and Southern Caspian provides evidence of shallow BSRs. At the same time, Caspian data shows unusual acoustic pattern as mirrored reflection. Very acoustically sharp layer "mirrors" bottom relies so that at first glance it could be confused with BSRs and. Interesting fact is, that such effect occurs nearby gas escaping areas.

\section{CONCLUSION}

Are sediment waves geohazards or just geofeature? After one had found some "wavy" morphology and classified it as creep, we are talking of geohazard, on the other way it seems undisturbed accumulative object. Nevetheless, every sediment wave field is (or was) forming in active environment such as water flow or turbidite. Two latter are treacherous processes, escpecially for pipelines: erosion could cause stretching while intensive sediment input could bury pipe. Other exploitetion and exploration risks are solifluction under pressure of platform basement and gas explosion. Thus such geofetures as sediment waves should serve as a warning and to think in advance of anthropogenic impact and to take care of the sea. 
The presented study was partially supported by RFBR, research project No.12-02-00543-a

\section{REFERENCES}

Marine Geology, (2002), vol.192

Berndt, C., Bünz, S., Clayton, T., Mienert, J., Saunders, M. (2004). Seismic character of bottom simulating reflectors: Examples from the mid-Norwegian margin // Marine and Petroleum Geology 21 (6), pp.723-733

Booth J.R., Dean M.C., DuVernay A.E. III, Styzen M.J. (2003). Paleo-bathymetric controls on the stratigraphic architecture and reservoir development of confined fans in the Auger Basin: central Gulf of Mexico slope // Marine and Petroleum Geology, v. 20, p. 563-586.

Diaconescu C.C., Kieckhefer R.M., Knapp J.H. (2001). Geophysical evidence for gas hydrates in the deep water of the South Caspian Basin, Azerbaijan Marine and Petroleum Geology 18, pp.209 221

Ginsburg, G. D., \& Soloviev, V. A. (1994). Mud volcano gas hydrates in the Caspian Sea // Bulletin of the Geological Society of Denmark, 41, 95 \pm 100

Glumov I.F., Malovitskiy Ya.P., NovikovA.A., Senin B.V. (2004) Regional geology and oil and gas content of Caspian Sea. (In Russian) Moscow, Nedra

Heinio P., Davies R.J. (2009). Trails of depressions and sediment waves along submarine channels on the continental margin of Espirito Santo Basin, Brazil // Geological Society of America Bulletin, v.121, no.5-6, p.698-711

Holbrook W.S., Lizarralde D., Pecher I.A., Gorman A.R., Hackwith K.L., Hornbach M., Saffer D. (2002). Escape of methane gas through sediment waves in a large methane hydrate province // Geology, v.30, pp. $467-470$

Mitchell N.C., Huthnance J. M. (2007). Comparing the smooth, parabolic shapes of interfluves in continental slopes to predictions of diffusion transport models // Marine Geology 236, 189-208

Putans V.A., Merklin L.R., Levchenko O.V. (2010). Sediment waves and other forms as evidence of geohazards (Caspian Sea) // International Journal of Offshore and Polar Engineering. Vol. 20, No. 4

Riedel, M., Collett, T.S., and Malone, M., (2010). Expedition 311 synthesis: scientific findings // In Riedel, M., Collett, T.S., Malone, M.J., and the Expedition 311 Scientists, Proc. IODP, 311:

Washington, DC (Integrated Ocean Drilling Program

Wynn R.B., Cronin B.T., Peakall J. (2007). Sinuous deep-water channels: Genesis, geometry and architecture // Marine and Petroleum Geology 24, pp. 341-387

\section{BIOGRAPHIES}

Victoria PUTANS, researcher in Seismostratigraphy lab in P.P.Shirshov Institute of Oceanology, RAS (IORAS). Since 2003 worked as part-time engineer in the IO RAS while being full-time student of Russian State Geological Prospecting Univ. (RSGPU), Geophysical Dept. Graduated RSGPU in 2007 as Mining engineer in geoghysical methods of prospecting and survey, Seismics. Continued in IO RAS as $\mathrm{PhD}$ student and recieved $\mathrm{PhD}$ in Oceanology in 2010. Participant of several international scientific projects, experience in exploration projects for Lukoil company. Current scientific interests: seismoacoustics, geohazards, sea-level change, marine exploration, all range of sedimentation processes. 


\section{CONTACT DETAILS}

Victoria PUTANS

P.P.Shirshov Institute or Oceanology, RAS

36, Nokhimovskiy prospekt

Moscow

RUSSIA

Tel.: +79263193636

Fax: +499124

Email: vitapu@mail.ru; vitapu@ocean.ru

Web site: www.ocean.ru 